\title{
Long term Urological complications in patients with Spinal cord injury
}

\section{Bikash Bikram Thapa, Dhan Bahadur Shrestha, Narayan Thapa and Bharat Bahadur Bhandari}

Department of Surgery, Nepalese Army Institute of Health Sciences, Shree Birendra Hospital, Chhauni, Kathmandu, Nepal

\begin{abstract}
Introduction: Neurogenic bladder (NGB) is common in daily urological practice; however, information on types of urological complications encountered in army and veterans are not under strict surveillance and little is known to them about the best way to manage the condition. This observational study aimed to determine the types of urological complications encountered in regular soldiers and veterans with traumatic spinal cord injury (SCI) with NGB, and the usage of bladder management programs to deal with NGB.

Methods: We retrospectively reviewed the charts and records of interviewed patients with SCI in our urology clinic. Demographic data collected included: age, gender, mode of injury and level of spinal injury. Also noted were episodes of urinary tract infection (UTI), renal lesions, and bladder program followed.

Results: The mean age of our study sample $(\mathrm{N}=63)$ was $40 \pm 10.8$ years and all were male. Age at onset of injury was $33.8 \pm 16.6$ years and duration since SCI insult was $90.6 \pm 54$ months. Symptomatic urinary tract infection $(75 \%)$, chronic cystitis $(53.3 \%)$, hydro-nephrosis $(36.5 \%)$ and urinary bladder calculi (33.3\%) were the common urological lesion observed. Indwelling Foley's catheterization is a method of urinary bladder management in $54 \%$ study population where urinary tract infection is more common $(\mathrm{p}<0.05)$.
\end{abstract}

Conclusions:Urinary tract infection, hydro-nephrosis and Urinary bladder calculi were the most common urological complications encountered in army and veterans with NGB. Indwelling Foley's catheter was the most frequently used bladder management program with the higher risk for UTI.

Key words: Neurogenic bladder; Spinal cord injury;Urinary tract infection

Correspondence: Bikash Bikram Thapa, Department of Surgery, Nepalese Army Institute of Health Sciences, Shree Birendra Hospital, Chhauni, Kathmandu, Nepal. Email: bbthapa@gmail.com

DOI: http://dx.doi.org/10.3126/mjsbh.v17i1.17732

Submitted on: 2017-07-13

Accepted on: 2018-02-23 


\section{INTRODUCTION}

Urological complications resulting from neurogenic voiding dysfunction (NVD) has historically been the leading cause of morbidity and mortality in individuals with spinal cord injury (SCI). ${ }^{1}$ Worldwide incidence of spinal cord injury has been reported up to 236-1009/million/year. ${ }^{2}$ Incidence of spinal cord injury has not been reported in Nepal. However, two studies from eastern Nepal have reported 382 spinal injuries (149 cervical in between 2001 to 2004 and 233 spinal cord injury in between 1997 to 2001).3, 4 The effect of spinal cord injury on the urethral sphincter and on the function of the detrusor muscle is the cause of neurogenic bladder dysfunction. ${ }^{5}$ The degree of damage to the voiding cycle depends on the location, completeness as well as the vascular extension of the injury.

The urologic function following SCI is generally categorized into three phases: (1) spinal shock, (2) recovery, and (3) stable phases. The stable phase represents the period when there are no further signs of neurologic recovery. ${ }^{6}$ Neurogenic bladder (NGB) is abnormal function of the urinary bladder secondary to any neuro-pathology whether involving central nervous system or the peripheral nerves involved in the control of micturition. ${ }^{7}$ The priorities in the management of NGB should be preservation of renal function, freedom from urinary tract infection (UTI), and efficient bladder emptying. 8 Some of the common urological complications following chronic SCI status are recurrent urinary tract infection, urinary incontinence and urolithiasis.

This study was conducted to determine the types of urological complications encountered in regular soldiers and veterans with traumatic SCI with NGB, and the usage of bladder management programs to deal with NGB

\section{METHODS}

It is a cross sectional retrospective study among the patients who sustained traumatic spinal cord injury for more than 1 year. Data retrieved from the hospital record system in formatted proforma. Demographic data including patient's age, gender, and mode of injury, duration of injury and level of injury were all recorded. Patients received neurological and urological examinations, including a physical examination, renal sonography, bladder sonography, and urinalysis. The level of SCI was classified based on clinical and radiological evaluation. Current bladder management was recorded. Urological complications and its management was recorded for symptomatic UTIs/year, hydro-nephrosis, urolithiasis, contracted kidneys, trabeculated bladder, and others. The urological complications analyzed according to type of bladder management, the duration and level of SCI. For all analyses, the variables were presented as patient number and percentage of the group. Categorical data were analyzed using appropriate statistical test.

Ethical clearance for the study was taken from institutional ethical review committee. Informed consent was obtained from each participant.

\section{RESULTS}

The mean age of all male of our study sample $(\mathrm{N}=63)$ was $40 \pm 10.8$ years (range 23 to 63 years). Average age at onset of injury was $33.8 \pm 16.6$ years (range 19 to 55 years) and duration since SCI insult was $90.6 \pm 54$ months (range 13 to 180 months). The most common cause of injury was fall from height $(47 \%)$ followed by blast injury $(30 \%)$. The spinal level of injury was cervical in $33 \%$, thoracic in $37 \%$, Lumbar in $27 \%$ and multiple levels in $3 \%$.

None of the individual had awareness about bladder management programme and the requirement of 
regular urological followed up. The most common form of urinary bladder management is indwelling Foley's catheterization (54\%) followed by Condom-catheter (45\%). 44 out 63 of individuals had one or more form of urological complications. $75 \%$ (47 out of 63 ) had recurrent symptomatic UTI. The mean symptomatic UTI/year/individual was $2.7 \pm 1.8$. Escherichia coli $(53 \%)$ are the most common microorganism followed by Proteus (10\%) among culture positive individuals. Ultrasonography showed chronic cystitis in 53.3\% and hydro-nephrosis in $36.5 \%$ and urolithiasis in $33.3 \%$. Mean duration for development of calculus was $6.4 \pm 3.3$ years. The episodes of symptomatic UTI/year in patients with indwelling Foley's catheterized group is higher (29 out of 35) than Condom catheter group (18 out of 28 ) with $p$ value $<0.05$. Urolithiasis was more frequent in patients with sacral SCI than other levels of SCI $(p=$ 0.056). There is no significant association between level of SCI and duration of SCI with rate of occurrence of urological complication $(p=0.2$ and 0.3 respectively).

\section{DISCUSSION}

After traumatic spinal cord injury (SCI), virtually all patients experience some form of neurogenic bladder (NGB) dysfunction. Well established urological complications from neurogenic voiding dysfunction include urinary tract infections, bladder and renal urolithiasis, hydronephrosis, severe urinary incontinence and renal failure. ${ }^{9,10}$ A survey of 894 individual with SCI done in Taiwan with mean age of $43.4 \pm 13.3$ years cervical region is the most common site of SCI which is comparable with our study result. Symptomatic urinary tract infection and hydro-nephrosis are most common urological complications noted among study population.10-12 The higher incidence of symptomatic UTI and chronic cystitis in our study are likely due to common use of indwelling urethral
Table 1. Urological complication among study population $(\mathrm{n}=63)$

\begin{tabular}{|c|c|c|c|}
\hline $\begin{array}{l}\text { Catheter } \\
\text { related } \\
\mathrm{N}=7, \\
(\mathbf{1 1 . 1 \% )}\end{array}$ & $\begin{array}{c}\text { Infectious } \\
N=50 \\
(79.3 \%)\end{array}$ & $\begin{array}{l}\text { Urolithias } \\
\quad \text { is } \\
n=21 \\
(33.3 \%)\end{array}$ & $\begin{array}{c}\text { Hydronep } \\
\text { hrosis } \\
\mathrm{N}=\mathbf{2 3}, \\
(\mathbf{3 6 . 5 \%})\end{array}$ \\
\hline $\begin{array}{l}\text { Retained } \\
\text { foley's } \\
\mathbf{N}=\mathbf{2}\end{array}$ & $\begin{array}{l}\text { Urethritis } \\
\mathrm{N}=10\end{array}$ & $\begin{array}{l}\text { Renal } \\
\text { calculi } \\
\mathrm{N}=6\end{array}$ & $\begin{array}{l}\text { Mild } \\
N=13\end{array}$ \\
\hline $\begin{array}{l}\text { Urethral } \\
\text { erosion } \\
\mathrm{N}=2\end{array}$ & $\begin{array}{l}\text { Chronic } \\
\text { Cystitis } \\
\mathrm{N}=33\end{array}$ & $\begin{array}{l}\text { Vesical } \\
\text { calculus } \\
\mathrm{N}=15\end{array}$ & $\begin{array}{l}\text { Moderate } \\
\mathrm{N}=7\end{array}$ \\
\hline $\begin{array}{l}\text { Urethral } \\
\text { injury } \\
\mathbf{N}=\mathbf{3}\end{array}$ & $\begin{array}{l}\text { Pyelonep- } \\
\text { hritis } \\
\mathrm{N}=7\end{array}$ & & $\begin{array}{l}\text { Severe } \\
\mathrm{N}=3\end{array}$ \\
\hline
\end{tabular}

catheter. Other lesions such as renal calculi, urethritis, urethral erosion, urethral stricture and epididymitis also depend upon how the NGB is managed. ${ }^{13}$

Various options for bladder management in SCI include clean intermittent catheterization (CIC), use of external (condom), indwelling (Foley) or suprapubic catheters where indicated. Since the initial recommendation in 1972 to use CIC for bladder management in patients with SCI, it is now the practice method preferred. ${ }^{14}$ None of our patient was instructed for CIC and overall incidence of symptomatic UTI/year was $75 \%$. Western literatures revealed the overall incidence of symptomatic UTI between $30 \%$ to $65 \% .{ }^{12,13} \mathrm{CIC}$ is a superior method for preserving bladder compliance and preventing upper tract complications associated with low compliance provided the patient is well instructed in the technique and the risk of CIC.11,15-17 The annual surveillance with renal ultrasound, renal function assessment, a frequency volume chart and a review of bowel/ sexual/ fertility issues is recommended for all patients with NGB following spinal cord injury to prevent urological complications and undesired lower urinary tract symptoms. ${ }^{18}$ Repeat 
urodynamic testing was recommended only for specific indications or previously concerning urodynamic findings. ${ }^{19}$ The European Association of Urology (EAU) created a guideline for the follow up of patient with neurogenic bladder that is much more extensive. ${ }^{20}$ Management of spinal cord injury is extremely difficult in the resource-limited countries like Nepal. With regular medical surveillance, occupational and psychological rehabilitation they can lead a independent and productive life. ${ }^{21}$

\section{CONCLUSIONS}

This study revealed that symptomatic urinary tract infection, hydro-nephrosis and urinary bladder calculi were the most common urological complications following spinal cord injury. Indwelling Foley's catheterization was most widely used method of urinary bladder management that results in higher incidence of lower urinary tract complications. Regular urological follow up along with patient's education for skill CIC is crucial to reduce the urological lesions.

To cite this article: Thapa BB, Shrestha DB, Thapa N, Bhandari BB. Long term Urological complications in patients with Spinal cord injury. MJSBH. 2018;17(1):38-43.

Conflict of Interest: None declared

\section{REFERENCES}

1. Gutierrez PA, Young RR, Vulpe M. Spinal cord injury. An overview. Urol Clin North Am. 1993 Aug; 20(3):373-82.

PMid:8351764

2. Cripps RA, Lee BB, Wing P, Weerts E, Mackay J, Brown D. A global map for traumatic spinal cord injury epidemiology: towards a living data repository for injury prevention. Spinal Cord. 2011 Apr;49(4): 493-501.

DOI: https://doi.org/10.1038/sc.2010.146 PMid:21102572

3. Shrestha D, Garg M, Singh GK, Singh MP, Sharma UK. Cervical spine injuries in a teaching hospital of eastern region of Nepal: a clinico-epidemiological study. J Nepal Med Assoc. 2007 Jul-Sep;46(167): 107-11.

PMid:18274565

4. Lakhey S, Jha N, Shrestha BP, Niraula S. Aetioepidemiological profile of spinal injury patients in Eastern Nepal. Trop Doct. 2005;35(4):231-3.

DOI: https://doi.org/10.1258/004947505774938756

PMid:16354480

5. Kinney TB, Rose SC, Valji K, Oglevie SB, Roberts AC. Does cervical spinal cord injury induce a higher incidence of complications after prophylactic Greenfield inferior vena cava filter usage? J Vasc Interv Radiol. 1996 Nov;7(6):907-15.

DOI: https://doi.org/10.1016/S1051-0443(96)70869-2

6. Watanabe T, Rivas DA, Chancellor MB. Urodynamics of spinal cord injury. Urol Clin North Am. 1996 Aug;23(3):459-73.

DOI: https://doi.org/10.1016/S0094-0143(05)70325-6 
7. Cameron AP. Pharmacologic therapy for the neurogenic bladder. Urol Clin North Am. 2010 Nov;37(4): 495-506.

DOI: https://doi.org/10.1016/j.ucl.2010.06.004; PMid:20955901

8. Weld KJ, Dmochowski RR. Association of level of injury and bladder behavior in patients with posttraumatic spinal cord injury. Urology. 2000 Apr;55(4):490-4.

DOI: https://doi.org/10.1016/S0090-4295(99)00553-1

9. Cameron AP, Lai J, Saigal CS, Clemens JQ. Urological Surveillance and Medical Complications after Spinal Cord Injury in the United States. Urology. 2015 Sep;86(3):506-10.

DOI: https://doi.org/10.1016/j.urology.2015.06.005

PMCid:PMC4979001

10. Sheng-Fu Chen Y-HJ, Jia-Fong Jhang, Cheng-Ling Lee, Hann-Chorng Kuo. Bladder management and urological complications in patients with chronic spinal cord injuries in Taiwan. Tzu Chi Medical Journal 2013;26:25-8.

DOI: https://doi.org/10.1016/j.tcmj.2013.09.010

11. Rabadi MH, Aston C. Complications and urologic risks of neurogenic bladder in veterans with traumatic spinal cord injury. Spinal cord. 2015 Mar 1;53(3):200-3.

DOI: https://doi.org/10.1038/sc.2014.205ＰMid:25403501 PMCid:PMC4436035

12. Ruutu M, Lehtonen T. Urinary tract complications in spinal cord injury patients. Ann Chir Gynaecol. 1984;73(6):325-30.

PMid:6529135

13. Singh R, Rohilla RK, Sangwan K, Siwach R, Magu NK, Sangwan SS. Bladder management methods and urological complications in spinal cord injury patients. Indian J Orthop. 2011 Mar;45(2):141-7.

DOI: https://doi.org/10.4103/0019-5413.77134～PMid:21430869

14. Lapides J, Diokno AC, Silber SJ, Lowe BS. Clean, Intermittent Self-catheterization in the Treatment of Urinary Tract Disease. J Urol. 2017 Feb;197(2):S122-4.

DOI: https://doi.org/10.1016/j.juro.2016.10.097 PMid:28012758

15. Weld KJ, Graney MJ, Dmochowski RR. Differences in bladder compliance with time and associations of bladder management with compliance in spinal cord injured patients. J Urol. 2000 Apr 30;163(4): 1228-33.

DOI: https://doi.org/10.1016/S0022-5347(05)67730-0

16. Wyndaele JJ, De Sy WA, Claessens H. Early urological complications in spinal cord injury patients treated with a foley catheter. Acta Urol Belg. 1981 Dec;50(3):335-42.

17. Hill VB, Davies WE. A swing to intermittent clean self-catheterisation as a preferred mode of management of the neuropathic bladder for the dextrous spinal cord patient. Spinal Cord. 1988 Dec 1;26(6):405-12.

DOI: https://doi.org/10.1038/sc.1988.62 PMid: 3226768

18. Nijman RJ. Neurogenic and non-neurogenic bladder dysfunction. Curr Opin Urol. 2001 Nov;11(6): 577-83.

DOI: https://doi.org/10.1097/00042307-200111000-00004ＰMid:11734693 
19. Abrams P, Agarwal M, Drake M, El-Masri W, Fulford S, Reid S, et al. A proposed guideline for the urological management of patients with spinal cord injury. BJU Int. 2008 Apr;101(8):989-94.

DOI: https://doi.org/10.1111/j.1464-410X.2008.07457.x PMid:18279449

20. Stohrer M, Blok B, Castro-Diaz D, Chartier-Kastler E, Del Popolo G, Kramer G, et al. EAU guidelines on neurogenic lower urinary tract dysfunction. Eur Urol. 2009 Jul;56(1):81-8.

DOI: https://doi.org/10.1016/j.eururo.2009.04.028 PMid:19403235

21. Shrestha D. Traumatic spinal cord injury in Nepal. Kathmandu Univ Med J (KUMJ). 2014 Jul-Sep; 12(47):161-2. 